\title{
Cerebral Apoplexy and its Rehabilitation in Rural Districts
}

\author{
by \\ Masashi Iто, M. D. \\ Department of Internal Medicine, Yuri Kumiai General Hospital
}

\begin{abstract}
Cerebral apoplexy in rural districts is in many cases caused by cerebral hemorrhage and occurs frequently in younger persons. However, according to recent statistics of mortality, cerebral hemorrhage is decreasing but cerebral infarction is increasing, similar to other districts. Seeing from the disease types obtained from our 182 dissected subjects in these 6 years (the dissection ratio, $78 \%$ ), the ratio of cerebral hemorrhage vs. cerebral infarction was 2.2 in the early half period but it became 1.1 in the late half, and cerebral hemorrhage decreased. However, seeing from the disease types of 670 in-patients in an acute stage, cerebral infarction is not always increasing, but the ratio of the infarction in those older than 60 years old raised from $49 \%$ to $71 \%$. It is noticed that cerebral hemorrhage is not always decreasing in those younger than 40 years old. In cerebral infarction the occlusion of main arteries increases recently to $34 \%$ from $6 \%$, and it presents a problem in the view of rehabilitation. The rehabilitation goal was researched in 430 subjects based on the type of disease: $77 \%$ of cerebral hemorrhage and $90 \%$ of cerebral infarction got the goal in the independent group: the former was inferior in this aspect. As to the patients of infarction, the goal was got in $33 \%$ of embolism in main artery occlusion in the independent group, in $67 \%$ of thrombosis and in $91 \%$ of the subjects having no main artery occlusion. The pregnosis of the embolic artery occlusion is unsatisfactory.
\end{abstract}

The effect of adrenocortex hormones was studied as to 166 cases in the acute stage of cerebral hemorrhage: it could improve the survival pregnosis within 1 month but could not improve the rehabilitation goal ratio.

The relapsed subjects admitted by the hospital for rehabilitation were pursued and the index for forecasting the prognosis (22 points being the full mark) was set: the relapse ratio was $3 \%$ in the subjects with less than 10 points and $26 \%$ with more than 11 points; the index was found to be effective in the internal check. 46 bodies were subjected to autopsy for the external check: the relapse was $0 \%$ with less than 10 points, $24 \%$ with more than 11 points and $71 \%$ with more than 15 points, and the index was found to be effective.

The patients of cerebral apoplexy who had been discharged from the hospital were followed up: $4 \%$ of them returned to their agricultural life and $13 \%$ returned to the non-agricultural occupation. The recovery ratio in the agricultural field was lower.

Besides what described above, the relation between the Rossolimo's reflex and the rehabilitation and the prognosis research on subarachnoidal hemorrhage were discussed. 


\section{研究と報告}

\section{農村における脳卒中とリハビリテーション}

\section{伊 藤 政 志*}

\section{I.はじめに}

わが国における脳卒中の 死亡は昭和 26 年以後 死因の第一位を占めているが，とくに農業従事者 の脳卒中が多く注目されている。

昭和 40 年の厚生省統計調査部の 資料から, 脳 卒中の産業別訂正死亡率をみると，農業は他の産 業に比べて群を抜いて高率で，全産業平均を $36 \%$ もオーバーして第一位である.

また病院のある秋田県は脳卒中県として有名で あるが，昭和 41 年の人口 10 万対の脳卒中死亡は 全国平均 173 に対して，秋田県は実に 250 となっ ている.

われわれの病院はこの秋田県の中でも一番南に 位置し，日本海に沿う本荘市由利郡という農村部 にあるが，この地域も例外でなくむしろ秋田県の それを上回わって脳卒中の多い所である，和泉 ${ }^{11}$ は昭和 39 年にこの地域（人口約 13 万）の脳卒中 後遺症患者の実態調查を行ない人口 1,000 人に対 し 5 人の脳卒中患者がおり，そのらち $35 \%$ ，お よそ 250 名は適当なリハビリを行なえば，機能の 回復がのぞめることを見い出した。この実態調査 の成績から病院では，昭和 41 年 5 月から機能訓 練施設，大運動浴槽をはじめとするリハビリ施設 をととのえ，120ベット（総ベット数 820）の脳 卒中リハビリをスタートさせたわけである.

つぎにわれわれの脳卒中リハビリの特徵をあげ るとつぎの 3 つなると思われる。

第 1 はこの 6 年間に 1,200 名の脳卒中患者を収 容してきたが，地域の唯一の総合病院，しかも第 一線病院に設けられたリハビリ施設なので，発作

* 由利組合総合病院内科
一週以内の急性期からの入院が 5 割を占め，急性 期からひきつづきのリハビリが可能であったこと である。

第 2 に，全例脳動脈写を行ない，また自ら行な った脳卒中剖検 180 例（剖検率 8 割）の内容から 病型診断がかなり適確にできたことである。

第 3 には病院の年間 5 万人をこす地域保健活動 の実績から退院後の患者の追跡調査が常に 9 割以 上可能であったことである.

また急性期からリハビリ，死亡，剖検さらには 追跡調査まで 1 人の内科医を中心に一貫して観察 されたのも特徽的である.

昭和 45 年 10 月，院長の 和泉 ${ }^{2)}$ は第 19 回日本 農村医学会総会で「農村に拈ける脳卒中」という 題で宿題報告を行ない，これまでの成績をまとめ て発表したが，今回はその後の調査を追加し述べ てゆきたい。

\section{II. 農村における脳卒中の実態}

農村における循環器疾患については和泉の宿題 報告の他 ${ }^{1)}$, 日本農村医学会でも，数々の特別講 演やシンポジウム2)がもたれている．これらを要 約して農村における特徵を一口に述べると若年か ら高血圧者が多く，また脳卒中では脳出血が，他 の地域に比し若い年齢層から多く発生しているこ とがあげられる。ここで秋田県由利郡の農村部脳 卒中の死亡率を昭和 25 年から 42 年まで, 5 年ご との平均でその推移をみると全国平均をはるかに 凌駕し減少どころかむしろ増加の傾向を示してい る。男女差はあまりないが，年齢階級別では70 歳以上の高齢者の割合が増加し，昭和 29 年の 30 \%より昨今は $44 \%$ と高率になっている。しかし 
発㗪 1 润以内入院

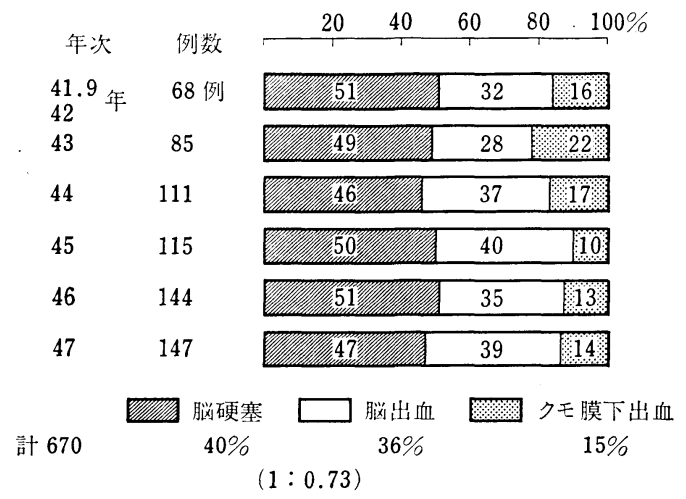

表 1 脳卒中剖検の年次病型推移（剖検率 78\% )

\begin{tabular}{c|c|ccc|c}
\hline 年 次 & 例数 & 脳出血 & 脳硬塞 & $\begin{array}{c}\text { クモ膜下 } \\
\text { 出血 }\end{array}$ & 出血 : 硬塞 \\
\hline S 41.9〜 & & & & & \\
42 & 13 & 8 & 3 & 2 & $2.2: 1$ \\
43 & 20 & 12 & 6 & 2 & \\
44 & 39 & 15 & 16 & 8 & $1.0: 1$ \\
45 & 41 & 20 & 18 & 3 & \\
46 & 33 & 16 & 15 & 2 & $1.1: 1$ \\
47 & 36 & 18 & 15 & 3 & \\
\hline $\begin{array}{c}\text { 計 } \\
(\%)\end{array}$ & 182 & 89 & 73 & 20 & $1.2: 1$ \\
& $(100)$ & $(49)$ & $(40)$ & $(11)$ &
\end{tabular}

図 1 急性期入院脳卒中の年次推移 670 例（全脳卒中 1212 例）

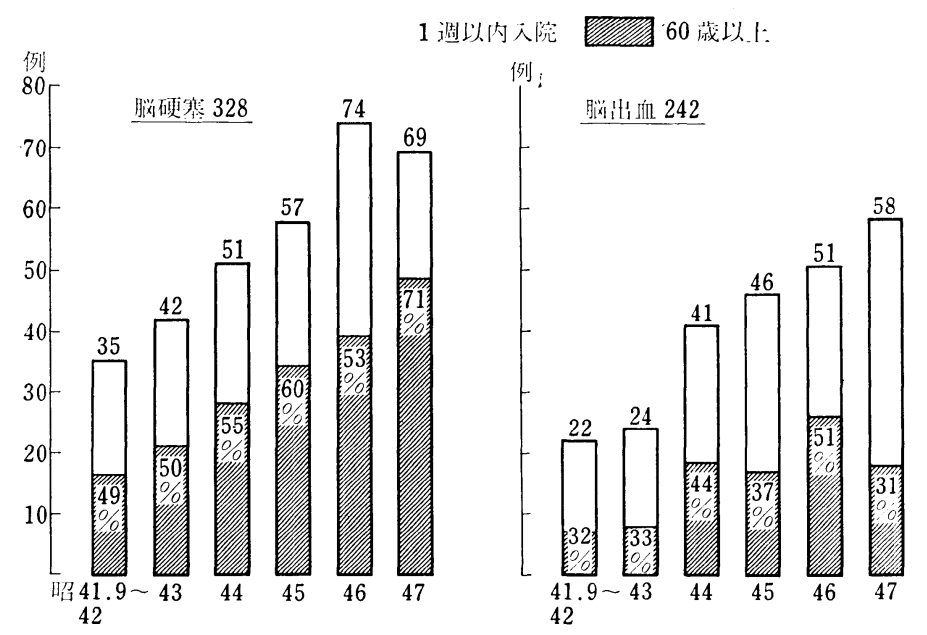

ここで 50 歳以下の 比較的若年 の脳卒中死亡の が $37 \%$ から 25 \%に少なくなっているが,なお かなりの数があり注目される.

つぎに信憑性に問題はあるが 死亡診断書でこの地方の脳卒中 病型をみると最近 10 年間, 脳 出血死亡数はほとんど変らない のに脳硬塞が約 3 倍にふえ出血 の対硬塞比は 10.2 力ら 3.6 に なっている。つぎにわれわれの 病院における最近 6 年間の脳卒 中剖検 182 例の病型をみると （剖検率 78\%）脳硬塞 1 に対し脳出血は 1.2 で死 亡診断書ほどないが，やはり脳出血の死亡の方が 多い。この間の年次推移をみると脳出血硬塞比は はじめの 2 年の 2.2 から 後半は $1.0,1.1$ 之横這 いで冲中研究班の成績4)に近いものになってきて いる(表 1 )。

脳卒中を死亡ではなしに脳卒中の発生でみてみ ると（図 1 ), 診断のつけやすい 1 週以内入院の 670 例の病型でみたが, 硬塞 : 出血は $1: 0.73$ で 久山町の $1: 0.3$ には及ばないが，やはり発生は 硬塞が多くなっている，ちなみに剖検でみた新鮮 例の正診率は $93 \%$ である。

新鮮発生の年次推移では剖検とは異なり脳硬塞 の増加は明らかでない.

つぎに急性期入院の 脳硬塞 328 例と脳出血 242

図 2 急性期入院脳出血, 硬塞之年次推移 570 例 (60 歳以上の割合, 昭 $41.9 \sim$ 昭 47.12)

例をとりあげ，各年次ごとの 60 歳以上の 占める 割合をみると, 脳硬塞では 42 年度 $49 \%$ より, 47 年度は $71 \%$ となり，高齢への移行が明らかであ る。一方脳出血では 42 年度 $32 \% ， 47$ 年度 $31 \%$ で必ずしも高年齢層にうつっているとはいえない ようである(図 2 ).

図 3 では急性期脳硬塞 328 例のうち, 主幹動脈 閉塞を示した 76 例の年次推移をみたものである. 昭和 42 年の $6 \%$ より 47 年には $34 \%$ 之, 主幹動 脈閉塞の増加が注目されるところである。後述す るように内包型の脳硬塞に比し, 主幹動脈閉塞の リハビリの成績がよくないが，この年次推移から 将来しだいにリハビリゴールの悪い症例がふえて くることが予想される。

図 4 は参考までに剖検例の脳動脈硬化を示した 


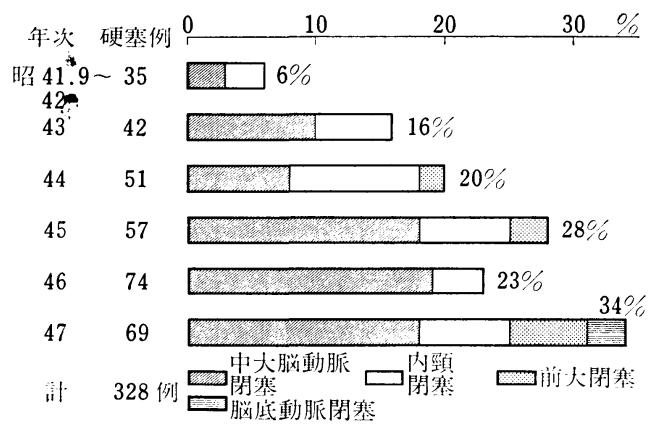

図 3 急性期入院脳硬塞と主幹動脳閑塞 76 例 (23\%)

ものである.脳動脈硬化度を Baker にならい, 日 米比較したものに秋田県由利郡内の剖検例を調 ベ，平均值を年齢別にプロットしたものである.

Baker Score は脳底部 Willis Ring 22 力所輪切 りにし狭窄度に応じて 1 点から 4 点まで点数をつ け，合計点で表すことになっている. 非脳卒中 44 例の Baker Score はアメリカのミネンタの成績 に比べるとかなり高值で, 勝木の成績とほぼ同じ か多少高めである。一方脳卒中 98 例をみると若 年から高度で 40 代でわずかに低い他, 各年齢で ほとんど差がなくなっている。 また Baker Score は高血圧と密接な関係があるが，コレステロール 中性脂肪とは一定の関係がなかった。このことは 脳卒中のリハビリ管理の面で大事で脂質対策よ り，高血圧対策がより重要である。

\section{III. 脳卒中病型とリハビリテーション成績}

脳卒中病型は機能訓練を行ならについてはさし て問題にならないが，急性期の治療にさいして は，これの決定は欠くことのできないものであ る. 全脳卒中の半数が 1 週以内入院（その 8 割は 3 日以内）といらわれわれの所では, せっかくつ けた急性期病型診断を, 生命の予後はもとより, リハビリのゴールの予想までもってゆきたいとい らのが念願である．脳卒中病型の決定は急性期の リコール所見と頸動脈写（症例によっては椎骨動 脈写併用）によってなされているが，ここでは頸 動脈写の所見を中心にしてリハビリとの関連を述 ベてみたい.

急性期 1 カ月を過ぎてリハビリのコースにのっ た症例 430 例のリハビリ成績5)をみると, ADL

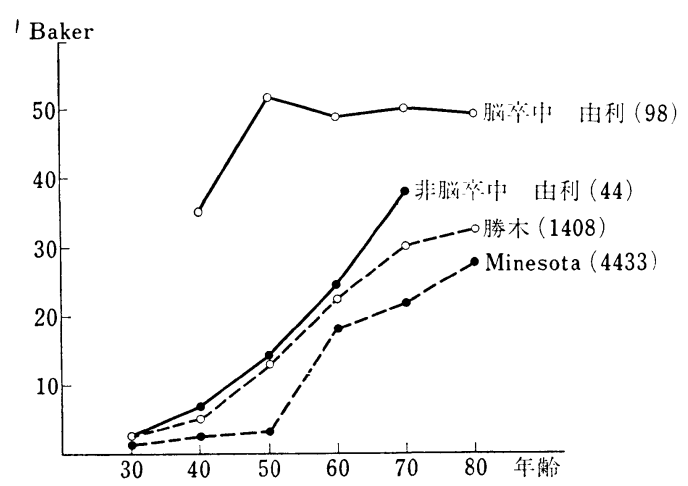

図 4 Baker Score と脳卒中

の変遷では入院時独立群の $48 \%$ が 退院時には 87 \%となり, $39 \%$ が新たに独立性を得ている。この らち日常注洎由ななんらかの意味で社会復帰を のぞめるものは, 開始時 $26 \%$ からゴール 時には 46\%になっている. 病型は脳出血 128, 硬塞 281, クモ膜下出血 21 で，男 283 , 女 113 , 平均年齢は 58 歳, 平均入院期間は, 3.7 カ月である。ここで 病型別にリハビリゴールをみると脳硬塞の独立群 は開始時 $57 \%$ が，ゴール時 $90 \%$, 脳出血では 43 $\%$ から $77 \%$ に，クモ膜下出血は $42 \%$ から $92 \%$ となりゴールのよいのは, クモ膜下出血, 脳硬 塞, 脳出血の順となっている.さらに日常ほぼ自 由なものはゴール 時脳硬塞 $60 \%$, 出血 $22 \%$, ク モ膜下出血 $87 \%$ で, やはりクモ膜下出血と硬塞 の予後がよい.リハビリ効果の点からいえば，脳 硬塞の独立性獲得は $90-57=33 \%$, 脳出血は, 90-42=35\% で出血硬塞で効果としては差がみ られない。つぎに脳硬塞のリハビリ成績を脳主幹 動脈閉塞の有無さらに, 主幹動脈閉塞を血栓性と 塞栓性に分けて調査 5 ,8)を試みてみた。対象は閉 塞のないもの 190 例, 平均年齢 58 歳, 主幹動脈 閉塞は 71 例, そのうち血栓性は 59 例, 平均年齢 59 歳, 塞栓性は 12 例, 平均年齢 57 歳である.リ ハビリゴールをみると独立群到達は動脈閉塞のな いもの $91 \%$, 血栓性主幹動脈閉塞は $67 \%$, 塞栓性 のもの $33 \%$ で，明らかに動脈閉塞とくに塞栓性

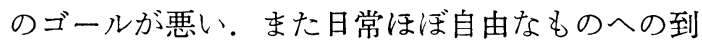
達は $62 \%, 27 \%$, $0 \%$ で同じような傾向である. リハビリ中の死亡をみると動脈閉塞のないもの 5 $\%$, 血栓性のもの $14 \%$, 塞栓性のものは実に 50 
\%で，ゴールと同様主幹動脈閉塞の死亡の多いの は注目に価する。

なお塞栓性主幹動脈閉塞の基礎疾患は僧帽弁狭 窄 2 , 虚血性心疾患 8 , 高血圧性心疾患 1 でいず れも心房細動を有し，急激な発症をきたしてい る. 動脈の閉塞部位では前大脳動脈, 内頸動脈分 岐部閉塞に比し中大脳動脈内頸サイフォン部閉塞 の予後がよくないようである.脳塞栓に関して は，ゴールがよくないこと，リハビリ中の再発 や, 退院後の追跡調査での再発死亡率が高いこと などから，これが予防のため抗凝血療法を試みて いるが，44例平均 11 力月の段階ではいまだ，効 果を明らかにしえないでいる。

つぎに脳出血の脳動脈写所見とリハビリ成績9) について考察をする。まず脳出血の特徴的所見で ある血管偏位としては, 缅動脈写動脈相の正面像 中, 前大脳動脈, 線状体動脈, sylvian group 動脈 をとりあげこれに側面像中大脳動脈 sylvian group 動脈の偏位を加味した, 初期の成績について述べ る. 臨床診断脳出血 240 例のらちなんらかの血管 偏位を示したものは73 例 (30\%) で，らち1週 以内入院の急性例 722 例では 62 例 $(51 \%)$ に血 管偏位が認められている。この偏位のうち線状体 動脈に関しては初期の造影に多小問題があり, 現 在ではおそらく急性例の $80 \%$ に偏位が認められ ると考えている，急性期脳出血 122 例のうち偏位 のあったもの 62 例の死亡は 41 例 $(66 \%)$, 偏位 のないものの死亡は 60 例中 18 例 $(30 \%)$ で偏位 のあるものの死亡が有意に多くなっている. 死亡 例のうち 45 例を剖検（76\% 剖検率）してみると 血管偏位 30 例のうちわけは混合型は $53 \%$ で一番 多く, 内側型 $23 \%$ 外側型 $17 \%$ である. なおここ で外側型といらのは内包より外側の出血, 内側型 は内包より内側の出血で混合型は両者を合併した ものである。偏位のないもの 15 例の 剖検内容は 橋出血 8 例, 両視床出血 3 例, 視床尾状核限局各 1 例であった。橋出血に頸動脈写上偏位がでない のはよいとして視床, 尾状核出血に偏位のみられ なかったのは注目すべきで，このため静脈相での 深部静脈の検討を行ないつつある。

つぎにその後の症例を加え 87 例の血管偏位例 を 5 型に分けて検討してみた。I 型は前大脳動脈
表 2 脳出血急性例の年次変化

\begin{tabular}{|c|c|c|c|c|}
\hline 年 次 & 症例 & 急性死 $(\%)$ & $\begin{array}{l}60 \text { 藏\% } \\
\text { 以上 }\end{array}$ & 手術例(死亡) \\
\hline $\begin{array}{l}41.9 \text { 〜2年 } \\
\text { }\end{array}$ & 22 & $9(41 \%)$ & 32 & $1(1)$ \\
\hline 43年 & 24 & $12(50 \%)$ & 33 & $2(2)$ \\
\hline 44年 & 41 & $18(44 \%)$ & 44 & $1(1)$ \\
\hline スイ 45 年 & 46 & $17(37 \%)$ & 37 & $3(2)$ \\
\hline D 46.8 & 33 & $9(27 \%)$ & 59 & $7(3)$ \\
\hline \multirow[t]{2}{*}{ 計 } & 166 & $65(39 \%)$ & 42 & $14(9)$ \\
\hline & & & \multicolumn{2}{|c|}{$\begin{array}{l}1 \text { 週以内入院 } \\
1 \text { 力月以内死亡 }\end{array}$} \\
\hline
\end{tabular}

の健側偏位と sylvian 群の外方偏位, II 型は前大 脳動脈の偏位と sylvian 群の内方偏位, III 型は 前大脳動脈の偏位と線状体動脈の内方偏位, IV 型は線状体動脈のみの内方偏位である.V型は sylvian 群の内方挙上である.

各群の死亡とリハビリゴール時の独立群到達を みると I 群 40 例では死亡 $83 \%$, 独立群到達は 10 $\%$, II 群 17 例では死亡 $59 \%$, 独立群 $24 \%$, III 群 8 例では死亡 $50 \%$, 独立群 $25 \%$, IV 群 19 例 では死亡 $21 \%$, 独立群 $47 \%, \mathrm{~V}$ 群は 3 例で死亡 2 例, 独立群 0 であるが症例少なく, はぶいてあ る.こうみてくると死亡もリハビリゴールも，I 群から IV 群に進むにつれて予後がよくなってい る.これを要約してみると線状体動脈の偏位が一 番よく,つぎに中大脳動脈の偏位で前大脳動脈の 偏位のあるものは一番よくない。ここで一番予後 のよい線状体動脈のみの偏位でも独立群到達は 47\%で，これまでの脳出血のリハビリゴール独 立群 77\% に比較して少ないようであるが, 前述 のリハビリ成績は発作後 1 カ月をすぎてからのも ので, 急性期の死亡がのぞかれているからであ る. 最近水上らは同じ線状体の内方偏位でも線状 体動脈の尖端が前大脳動脈を回避する，「内方回 避型」は生命の予後もリハビリの成績もよいと述 ベている．われわれも追試を行なったが線状体動 脈内方偏位 40 例のらち内包回避は 10 例, 回避な し 23 例, 回避判定不能 10 例 (23\%) であった. 回避例 の死亡は 2 例 $(20 \%)$ 独立群到達は 7 例 (70\%) に対し, 回避なしは死亡8例 $(35 \%)$ に 独立群 8 例 $(35 \%)$ で回避例の生命の予後もリ八 ビリ成績もよいようである。しかし死亡が 2 例あ 
表 3 急性期入院脳出血の退院時 ADL（副腎皮質ホルモン使用有無）

\begin{tabular}{|c|c|c|c|c|c|c|c|c|}
\hline 副 ホ & 年 次 & 死亡 & ねたきり & 日常要介助 & 日常独立 & ほぼ正常 & 死 $(\%)$ & 独立群 $(\%)$ \\
\hline $\begin{array}{c}\text { 無 } \\
46 人\end{array}$ & $\begin{array}{c}\text { 41.9. 42年 } \\
\text { 43年 }\end{array}$ & 22 & 3 & 4 & 7 & 10 & $48 \%$ & $37 \%$ \\
\hline $\begin{array}{c}\text { 有 } \\
33 \text { 人 }\end{array}$ & $\begin{array}{c}46 \text { 年 } \\
8 \text { 月迄 }\end{array}$ & 13 & 5 & 2 & 8 & 5 & $43 \%$ & $39 \%$ \\
\hline
\end{tabular}

り必ずしも絶対的なものではない様である。なお 内方回避の有無と入院時のリコール所見, 圧, 意 識レベルの間には一定の関係がなく, やはり回避 の有無をみるには頸動脈写が不可欠の様である。

\section{IV. 急性期脳出血に対する副腎皮質ホル モン使用とリハビリテーション成績}

昭和 45 年秋田県の公的医療機関 33 カ所にアン ケートを送り, 急性期脳出血の頭蓋内圧光進に対 しステロイドを使用しているかどらか回答を求め たところ 17 施設 $52 \%$ が積極的に大量療法を行な っていた2). 脳卒中に対するステロイド療法の根 本は脳浮腫の予防と進展防止にあるが，この機序 は血液脳関門の防衛と細胞膜の正常化をはかるこ とにあるとされている，著者も積極的治療派の 1 人としてステロイドを使っているが実際には効果 はどうなのであろらか. 正確なコントロールをお いての比較は難しいが一応の線をだすべく検討を 試及た。表 2 は脳出血症例 166 例の入院の年次推 移をみたものであるが，すべて 1 週以内の入院で その 8 割は 3 日以内の入院である. 発症後 1 力月 以内の死亡をみると 41 年 9 月から 44 年までは 40\% から 50\% の死亡率であるが，45 年になる と $37 \% ， 46$ 年は $27 \%$ まで減少してきている。 こ れを治療の面から調べると，この 45 年は積極的 にステロイドを採用し，全症例に用いた年にあた る。また 46 年は脳外科による手術の多い年でも ある．各年次ごとに重症例もまちまちで厳密には 比較はできないが， mass としてみればそう片よ りがないと思うので, このデータはステロイド療 法の有効性を暗示しているようである，ステロイ ドにより急性期死亡（1 カ月以内）は減少してい るよらであるが，リハビリ終了時の時点ではどう であろらか. 表 $3 に$ 示すようにまったくステロイ ドを使わなかった 43 年度までの 46 例と全例ステ ロイドを使った 46 年の 33 例を比較すると, ステ
ロイド非使用例も，使用例む退院時，死亡は 22 例 $(48 \%) ， 13$ 例 $(43 \%)$ で差がなく，また退院 時独立 群 到達は 10 例 $(37 \%)$ と 5 例 $(43 \%)$ で これもまた差がみられていない。つまり長い目で みればステロイドは生命の予後もリハビリ成績も 変えるほど強力でないといえる。わずかに生命を 引きのばす効果はあるようである.われわれのス テロイド治療は大量短期投与で初日デキサメザン゙ ン $16 \mathrm{mg} ， 2$ 日目 3 日目 $8 \mathrm{mg}$ ，以後 2 日ごとに漸 減して 1 週で中止とい5ことにしているが，ここ でステロイドホルモンの副作用のなかでもっとも 重大な消化管出血について調べてみた．急性期入 院で 1 力月以内に死亡したものの剖検例は 40 例 であるがこれらについてみてみると，ステロイド 使用前の 消化管出血は 15\% 使用後は $7 \%$ で，む しろ使用後は少なくなっている，われわれの行 なっている 1 週くらいのステロイド使用では消化 管出血は問題にならないようである.

\section{V. ロッソリモ反射とリハビリテーション}

ロッソリモ反射は，これを病的反射とするか異 論があるし，反射そのものの性格についても未知 のところが多い. しかしわれわれが日常脳卒中患 者をみているとロッソリモ反射のよくでる人に下 肢の㾏性が強く, また㾏性が弱くともいずれ強く なってくるような印象をうける。ここではまず口 ッソリモ反射と脳卒中の臨床的な事項との関係に ついて述べ,つぎに元浴風会病院 PT 伊藤直栄 氏考案による下肢の病性除去法を試み, その際の ロッソリモ反射の消長を追加してみたい，調査対 象は脳出血 48, 脳硬塞 40 , 両者の合併 9 例の 97 例で, 男 61 例女 36 例, 平均年齢は男 55 歳女 60 歳である.97例中ロッソリモ反射の陰性者は 25 例 (26\%), 麻盘側ロッソリモ陽性者 39 例 (40\%), 麻疩と反対側のロッソリモ陽性者 7 例 $(8 \%$ ) 両 側陽性者 26 例 $(27 \%)$ である。これらの $\mathrm{ADL}$ 
表 4 リハビリ中再発予想 Index
1) 入院時 60 歳以上
2) 眼底 Sheie $S_{3} \sim S_{4}$ 4 点
3) 入院時要介助
4) CVA 再発作例
5） $\mathrm{CAG}$ 動脈硬化中等度以上
計
5
4
22 点

をみると独立群はそれぞれ $56 \% ， 14 \% ， 23 \%$ で， 麻痺反対側にロッソリモのでるもの之両側にでる ものの ADL がよくなく重症のものが多い上らで ある．脳出血と硬塞でロッソリモの出方を調べる と, 出血では 48 例中 39 例 $(81 \%)$ が，硬塞では 4 例中 25 例 $(61 \%)$ が陽性で，出血の方がやや多 いようである。また両側と反対側にロッソリモの 出る者は出血 28 例 $(58 \%)$, 硬塞 10 例 (24\%) でこれも出血に多く, 重症例の多いのを裏がきし ている.

年齢とロッソリモ出現には一定の関係がみられ なかったが，発症後経過とは密接な関係が認めら れた。すなわち，ロッソリモ反射陽性者は発症後 3 カ月 までは 7 例中 2 例 $(28 \%) ， 3 \sim 6$ カ月で は 19 例中 13 例 $(68 \%) ， 6$ カ月以上では 71 例中 57 例 (80\%) ではじめに感じていたように，発 症後経過とともにロッソリモ陽性者が徐々にふ え，おそらく痤性発現に伴うのであろら。つぎに 伸展位での足クローヌスとロッソリモとの関係を みたが，ロッソリモ陽性者 72 例中クローヌス陽 性 43 例 $(60 \%)$ ，ロッソリモ陰性例ではクローヌ ス陽性 3 例（12\%）で，ロッソリモ陽性者にクロ 一ヌスが多い。つまり痤性の 1 つの表現と考えら れる足クローヌスとロッソリモはある程度平行す るといらわけである。ただ当初ロッソリモがクロ ーヌスに先行または平行するという考えは，ロッ ソリモ陰性であるにもかかわらずクローヌスので たものが 3 例あり，完全にはゆかないよらであ る。つぎに伊藤 PT の指導で行なった足の痤性 除去法について述べる。これは氏の考案になるも ので脳性小児麻盘の病性軽減に著効のあった方法 である，足関節を背屈位に十分矯正，固定するも ので, PT が徒手で行なったり，板で 20 分間固 定する方法がとられた。平均治療期間は 1 力月で ある。痙性除去法を行なった人 18 例ではロッソ
表 5 Index の Internal check

\begin{tabular}{|c|c|c|c|}
\hline 再発 Index & 症例 & 再発 & 再発\% \\
\hline $0 \sim 5$ 点 & 133 & 2 & \multirow{2}{*}{$3.4 \% *$} \\
\hline $6 \sim 10$ & 68 & 5 & \\
\hline $11 \sim 15$ & 46 & 13 & \multirow{2}{*}{$26.1 \% *$} \\
\hline $16 \sim 20$ & 11 & 2 & \\
\hline \multirow[t]{2}{*}{ 計 } & 258 & 22 & $8.5 \%$ \\
\hline & & \multicolumn{2}{|c|}{$* \mathrm{P}<0.01$} \\
\hline
\end{tabular}

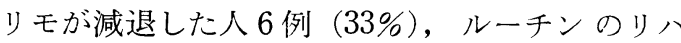
ビリのみの人 79 例ではロソリモ減退した人 9 例 $(11 \%)$, 逆に元進した人が 3 例 $(4 \%)$ みとめ られた。ロッソリモ反射を痓性の 1 つの表現とし てみればこの病性除去法はある程度有効だったと 思われる，つぎにこの治療法を行なった人の自覚 症状を聞いてみたところ，歩きやすくなった人は 半数あったが，予想に反しロッソリモの減弱とは 一定の関係がみられなかった。

\section{VI. リハビリ中の合併症と再発 (再発予想 Index)}

細卒中のリハビリテーションを行ならさい，再 発や合併症の危険を予知することはきわめて重要 なことであるが，その予想が困難なために安全性 を重く見すぎ，ときに必要な訓練もセーブされる ことがあるように思われる。このため諸家により その施設での再発, 合併症の実態がいろいろ報告 され，リスク管理が行なわれているが，われわれ も自ら経験したリハビリ中の死亡例, 再発例, 合 併症を検討し, 一歩進めて再発については, その 再発のメドをつける再発予想の Index を考案し てみた7)。その後症例を重ね，この Index の Internal check だけでなく External check も行な ってみたのであわせて述べてみたい.

調査対象は発症 1 カ月以上を経過しベッド上訓 練, テルテングを行なってからの症例 430 例で, これらの病型, 年齢, リハビリ成績については脳 卒中病型とリハビリ成績の項で述べたとおりであ る.

リハビリ期間中の死亡 24 例の死因をみると脳 卒中再発 10 例, 再発後肺炎で 死亡 3 例, 感染裖 創などによる全身衰弱 6 例であるが，この 19 例 は広義の脳卒中死で死因の大部分を占め，この他 
表 6 剖検例による External check

\begin{tabular}{crcc}
\hline 再発 Index & 症例 & 再発 & 再発\% \\
\hline $0 \sim 5$ 点 & 0 & 0 & 0 \\
$6 \sim 10$ & 10 & 0 & 0 \\
$11 \sim 15$ & 29 & 7 & $24 \%$ \\
$16 \sim 20$ & 7 & 5 & $71 \%$ \\
\hline 計 & 46 & 12 & $26 \%$
\end{tabular}

の死因としては心筋硬塞, 肺硬塞, 子宮癌など 5 例がある. 死亡例は初発病型入院までの期間, 入 院の長短には関係なく, 59 歳以下 $3.7 \%, 60$ 歳以

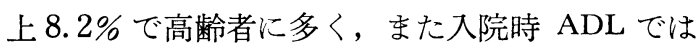
要介助者にの久死亡者がみられている。ここで再 発死亡 13 例の当時のリハビリ種目と再発状況を みると, 訓練段階はいろいろであるが, 11 例は ベッド休息中，その他は食事中の 1 例と検查中が 1 例で訓練中の再発死亡は 1 例も 又られなかっ た。諸家により報告されているように訓練中の再 発が少ないのは強調されてよいと思う。再発病型 は脳硬塞 11 例, 脳出血 2 例で, 脳出血例はテン カン発作中と TIA 頻発のため抗凝血療法施行中 の症例である。つぎにリハビリ中の主要合併症を みるともっとも多いのは尿路感染 39 , つぎに再 発が 23, 肺炎 10, 骨折 8 , 狭心症 7 , 異所性化 骨 3 ，症候性テンカン 14 などがあげられた。

脳卒中合併症, 偶発事故のなかでもっと光重大 なものは脳卒中の再発である. 脳卒中急性期 1 力 月以内の死亡は $24 \%$ であるが再発のそれは $65 \%$ と再発の死亡率はきわめて高い，そこでどういう 因子が再発に関与しているか検討を試みた。検討 項目は 16 で入院 時 年齢, 入院時 $\mathrm{ADL}$, 入院時 CVA が再発性のものか, 眼底所見, CAG 上の 動脈硬化の程度, 脳卒中病型, 性別, 発症より入 院までの期間, 脳主幹動脈閉塞の有無, 入院時血 圧, 尿蛋白の有無, 心電図所見, 心房細動の有 無, コレステロール, 糖尿病の有無, 症候性テン カンの有無である.このなかで再発の条件として

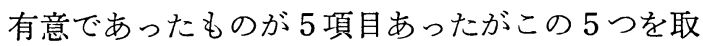
りあげ，佐野の頭部外傷のさいの Haematom Index にならい, 重要度に応じて点数を配分して再 発予想の Index をつくってみた。点数は再発率 の差を対数にとり四捨五入して簡略化してある. 入院時 60 歳以上 4 点, 眼底 Scheie $\mathrm{S}_{3}, 45$ 点, 入
院時要介助 4 点, 再発の CVA で入院したもの 5 点, $\mathrm{CAG}$ 上動脈硬化中等度以上 4 点で計 22 点で ある（表 4)。この Index をデータの揃った 258 例で検討してみたところ (Internal check) 10 点以 下の再発わずかに $3.4 \%$ にたいし，11点以上は $26.1 \%$ の再発で対象の $1 / 4$ 再発汸起こり再発 予想のうえでこの Index は有用のようである(表 5 ).

その後症例をふやし Index をつくって以後に 入院し死亡, 剖検した症例について External check を行なってみた。

46 例の剖検例 のうち 10 点以下 の 症例は 10 例 あったが，再発は 0,15 点までの 症例 29 例では 7 例 $24 \%$ が再発死亡, 15 点以上 7 例では 5 例 71 \%が再発死亡し，この再発 Index は十分実用に なるよらである，合併症についても二，三検討を 行なってみた。てんかん発作は脳卒中発作後いろ いろの時期に起こり一定の傾向はなく, 病型では 主幹動脈閉塞に多く, 入院時 ADL では重症例に 多く発作が起きている. 骨折 8 例では発作後 1 年 以上のものに 6 例生じ, 部位では大腿骨頸部骨折 が 6 例でもっとも多い. 尿路感染は ADL で重症 のものに多いが入院時尿蛋白の有無之は関係な い。またリハビリ中の狭心症発作は 7 例にみられ たが，入院時心電図異常とは一定の関係がみられ ず注目される。

\section{VII. 脳卒中退院患者の Follow up 成績}

脳卒中患者のリハビリテーションを扱っている ものにとって退院後の患者の状態はもっとも関心 を引くものの 1 つである. 重大な基礎疾患, 合併 症をもつこれら患者の生命の予後, 再発の状況, 自宅での ADL, 職業復帰の状況なぞは, リ八ビ リ中の患者の将来の姿をえがくためにぜひ知って おきたいことである．事実患者や肉親よりいろい ろ予後の質問をらけ困惑することがある，著者は 昭和 41 年に 秋田労災病院在任中, リハビリを行 なった 9 年間の脳卒中患者 305 例の予後を調查し 発作後平均 4 年数力月の 経過で $24 \%$ の患者が死 亡しているのを見出し驚いたことがある，諸家に より各施設での Follow up 成績がだされている が, 脳動脈硬化のつよい秋田の農村での退院後調 
查6)は他の地域との比較といらことでも意味のあ ることである。

調查対象は男 211 例女 97 例, 計 308 例 で平均 年齢はそれぞれ 57 歳之 60 歳, 平均入院期間は, 3.6 力月, 平均退院後期間は 1 年 2 力月, 臨休診 断名では脳出血 90 例 (29\%), 脳硬塞 203 例 (66 $\%)$ ，クモ膜下出血 15 例（ $5 \%$ ）である. 調查は アンケートによったが回答の得られぬものには病 院の地域保健担当の保健婦をと戚して, 市町村の 保健婦によるききとり, あるいは退院後の主治医 への問合せによった，回答率は $95 \%$ である. 入・ 退院時, 調查時の ADL の変遷は, 独立群は入院 時 $53 \%$ が退院時 $88 \%$ となり 調査時には $91 \%$ と なっている。日常ほぼ自由で社会復帰を望める人 は入院時 $29 \%$ 退院時 $50 \%$ 調査時 36\% で退院時 より減少している，寝たきりの人の割合は退院時 $13 \%$ から調查時 $10 \%$ とほぼ変っていない。注目 すべきは, 平均 1 年 2 力月の 経過 で死亡例が 30 例 $(10 \%)$ みられたことである。退院時の ADL 別に調查時の ADL を調べてみると, 退院時寝た きり 20 例では実に 10 例 $(50 \%)$ が死亡し, 残り の大部分はそのまま寝たきりの状態である，和泉 がこの地方の寝たきり脳卒中 163 例について調べ たさい, 3 年 2 力月後 $62 \%$ が死亡していたが, やはり半数は 1 年から 2 年の間に死亡していた。 一方独立群の死亡は $6 \%$ にとどまり，ADL でも 多小の改善と悪化がみられている.つぎに死亡 30 例の死因とあたり直し， 6 例の内容について述べ る。再発は 17 例 $(5.5 \%)$ にみられたが，このう ち 11 例は死亡し, 死亡率は $65 \%$ で 急性期死亡

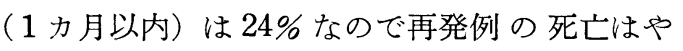
はり高率である. 死亡 30 例の死因をみると, 脳 卒中再発 11 , 精神異常 (痴呆) 4 , 全身衰弱 (裖 創肺炎） 4 , 心不全 3 , 糖尿病 2 , 自殺 2 , 胃癌 肝癌 2 , 肺結核 1 , 急性心臟死 1 であるが, 再発 死亡と精神異常, 全身衰弱の間接脳卒中死を合わ せると脳卒中死亡は死因の $63 \%$ となり諸家のい うように一度脳卒中に罹った人はやはり脳卒中で 死亡する人が多くなっている，その他の死因とし て自殺の 2 例があるが，いずれも手足がほぼ自由 になった症例で, 退院後のアフターケアーの重要 性を示唆している.つぎに退院時の ADL と死因
をみるとねたさりの 10 例 では 全例脳卒中死であ るが，独立群では 10 例中 2 例 が脳卒中死である にすぎない。

つぎに社会復帰状況をみるともとの仕事につい ているものわずかに $8 \%$, もとの仕事をいくら かと家事を汪とんどといらもの $13 \%$, 新しい仕 事についたもの $2 \%$ で合わせても $23 \%$ にすぎな い.

$40 \%$ から $50 \%$ の社会復帰という諸家の報告に 比し成績がよくないが，これはわれわれの症例が 急性期からひきつづきの患者が多いため, 重症の ものが無選択にリハビリに移行することと, 職業 復帰の職種が農業といら重労働が多いためと思わ れる。ちなみに職業復帰を農と非農に分けてみる と完全復帰例は農 $4 \%$ に対し非農は $13 \%$ になっ ている.

われわれは農村における脳卒中のリハビリは， 農業の特殊性から, 直接生産的な原職への復帰よ りもむしろ日常生活において家人の介助をらけ ず，身のまわりだけは自分でできるといったとこ ろ主目標を扣き, 家族がかわって農業の専念で きるよらにすべきだと考えている，ここで病型別 の再発の内容について述べてみたい. 調查した対 象は秋田労災病院の症例 308 例で主として秋田県 北部の症例であるが, 脳出血 82 , 血栓 196 , 塞栓 11 で平均年齢は 53 歳, 56 歳, 49 歳である. 平均 発症後経過年数は, それぞれ 4 年 10 力月, 4 年 5 力月, 2 年 6 力月である。再発は 305 例中 84 例にみられたが, 病型では出血, 血栓の再発は $20 \%$ 宛で差がないのに，塞栓の再発は $45 \%$ で経 過年数が短いのに多くなっていて注目される. 再 発死亡についても同様で, われわれが脳塞栓例に 抗凝血療法を試みているのはこれの再発防止に着 目したものである、脳出血と硬塞をとりあげ, 再 発の時期をみてみると再発も再発死亡も発作後 3 年目にピークがあり中風 3 年という諺を裏がきし ているようである。つぎに再発作時の病型を調べ てみた，初回発作血栓で再発も血栓のように，初 回・再発とも同じものをホモ, 違らものをへテロ としてみると， ホモの再発 44 にたいしへテロが 23 あり（不明は除いた）初発が血栓でも再発必 ずしも血栓でないようである. 再発時の病型別に 
死亡をみると出血 $81 \%$, 血栓 $21 \%$ ，塞栓 $71 \%$ で いずれも初回発作よりも死亡率が高い.

\section{VIII. クモ膜下出血, 脳動脈瘤患者の予後調査}

脳卒中のリハビリ対象のなかでクモ膜下出血の 占める割合はたかだか $5 \%$ ぐらいでそう多いも のではない。またりハビリ成績も他の病型に比し 良好である. しかしクモ膜下出血の急性期の予後 は悪く，とくに発作 10 日前後にみられる再発は 重要でわれわれも多くの症例を失っている。クモ 膜下出血の原因である脳動脈瘤手術の目的はこの 再発を防止することが第一であるが，再発のピー クの 3 週を生きのこり,さらには 2 カ月以上過ぎ てから,リハビリのコースに入った患者に手術を すすめるべきかどうか，リハビリ患者のリスク管 理を行なっているものにとって重大な問題であ るままた脳硬塞，脳出血でありながら脳動脈瘤を もっている症例があるが，これも手術をすべきか どうか考えさせられる．これらの解決の系口をつ かむために予後調查10)を行なってみたので述べ てみたい，予後調査の対象を述べる前にこの地域 におけるクモ膜下出血と脳動脈瘤の内容にふれて みる.

脳卒中 1015 例の段階でクモ 膜下出血は 107 例 あり，全脳卒中の一割を占める。動脈瘤はそのう ち 67 例 $(62 \%)$ に発見されているが，その他の 脳卒中では脳出血 314 例中 6 例之脳硬塞 594 例中 18 例にも動脈瘤が見い出されている．合わせる と 91 例になり，脳卒中全体の $9 \%$ にみられるこ とになる。発生部位は前交通動脈と中大脳動脈に 多く, 35 例宛 $(38 \%)$ で後交 通 動脈, 内頸動脈 にはそれぞれ 10 例 $(11 \%)$ と 5 例 $(6 \%)$ にす ぎない。つぎにクモ膜下出血の急性期の予後をみ てみると，対象は発作 1 週以内の 84 例であるが， 発作後 2 力月以内に 25 例 $(30 \%)$ が死亡してい る. 死亡は発作 3 日 以内之 10 日前後に 2 つのピ 一クがあり， 3 週すぎるとぐっと減少している. 10 日の山は再発によるものである.

さて追跡調査はアンケートによったが回答率は $97 \%$ である。対象は急性期 2 力月をすぎたクモ 膜下出血 87 例之動脈瘤をるつ。午の他, 脳卒中 18 例である。 クモ膜下出血を 3 つに分け, 調査
を試みた。動脈瘤を手術した人 13 例，手術しな い人 20 例，動脈瘤のみつからぬ人 36 例である. 経過年数と平均年齢 はそれぞれ 2 年 7 力月で 41 歳, 5 年で 56 歳, 2 年 11 力月で 55 歳である. 偶然発見動脈瘤の人は 18 例で 2 年 3 力月の経過 で 59 歳である。対象の死亡をみると 89 例中 14 例 $(16 \%)$ である。急性期に手術をした人は 9 例 であるが，その後の死亡は 1 例もない，非手術 例のらち 4 例は急性期を過ぎてから手術をした が， 2 例失われた。非手術例では 20 例中 5 例死 亡したが再発によるものは 2 例 $(10 \%)$ のみで他 は肺炎 2 例之脳硬塞 1 例（剖検）である。動脈瘤 のなかった 36 例の 死亡は 2 例，動脈瘤のあるそ の他脳卒中 18 例では 5 例死亡しているが，いず れも心不全, 脳硬塞で, クモ膜下出血による死亡 はなかった。これからみると急性期 2 力月を過ぎ たクモ膜下出血はたと充動脈瘤があっも平均 5 年 観察で 10\%なのでそんなに多いものでないこと になる．動脈瘤の発見されぬもの，あってもクモ 膜下出血のないものは，まず 3 年はクモ膜下出血 による死亡は考慮に入れなくてよいようである.

手術しない脳動脈瘤の予後は Sahs（アメリカ） らの広範囲な業績があり 830 例 2 力月から 3 年ま での死亡 $10 \%$ という成績があるが 奇しくもわれ われの成績と一致している，人によっては動脈硬 化の強い人はクモ膜下出血の再発は少ないと述べ ているが，動脈硬化の強い秋田農村でもアメリカ と同じような結果がでたわけである。

さて急性期を過ぎた脳動脈瘤破裂の人はどうす べきであろらか。これを決めるには手術成績が多 いに関係してくるが，現段階ではよいところで 5 \%ぐらいの手術死亡のようである，現在われわ れは対象に農民が多いことや, 経済的な事情も考 え合わせて，稼動能力のある 60 歳前の人には手 術をすすめ，それ以上の人には再発の多くないこ とを説明してノイローゼにしないようにつとめて いる. もちろん片麻痺のつよい人, 合併症のひど い人には手術をすすめないでいる。

つぎに退院後の ADL であるがクモ膜下出血の 三群は復職も，一部稼動も30\% 宛で差がみられな かった。一方動脈瘤をもつ脳卒中では, 復職, 一 部稼動 $23 \%$ であるが，寝たきりが $17 \%$, 死亡 28 
\%で動脈瘤のない畄卒中の成績よりかなりおち るよらであった。

\section{IX. よぬ}

農村に打忛る脳卒中の実態, リハビリ成績, 社 会復帰の状況など, 秋田県農村部の成績を中心に 述べた。

\section{文 献}

1）和泉昇次郎・他：秋田県本荘由利地方における 脳卒中後遺症患者の実態調査（第 1 報），（第 2 報)。秋農誌， 12(2)：1，1965.

2) 和泉昇次郎：農村における脳卒中。農村医学, $19(4): 219,1971$

3）和泉昇次郎・他：農村における成人病の現況々 将来. 臨床成人病, 2(12) : 1747, 1972.

4) 冲中重雄 - 他: 脳血管障害の疫学的研究一全国 17 力市町村における過去 5 力年間の追跡成績. 日本医事新報, No. $2352: 3,1969$.
5）伊藤政志・他：由利本茫の脳卒中（第 6 報）脳主幹動脈閉塞 37 例とそのリハビリテーショ ン成績. 秋医誌, 21(2): 114, 1969.

6）伊藤政志・他：由利本荘の脳卒中（第 7 報）脳卒中リハビリテーション退院患者由利組合総 合病院 308 例秋田学災病院 305 例の追跡調查. 秋医誌, 22(1)：1，1970.

7）伊藤政志・他：由利本茫の脳卒中（第 8 報）脳卒中 430 例のリハビリ中死亡と合併症.

(再発予想基準の評点化の試み)，秋医誌， 22 (2) : 85, 1970.

8）伊藤政志・他：由利本荘の脳卒中（第 9 報）脳塞栓による脳主幹動脈閉塞とリハビリテーシ ヨン成績, 秋医誌, 23(1) : 21, 1971.

9）伊藤政志・他：由利本荘の脳卒中（第 10 報）脸卒中を主とした脳血管写の 1000 例一副作用 と血管偏位について一 秋医誌, $23(2): 128$, 1971.

10）伊藤政志・他：由利本乼の脳卒中（第 11 報）クモ膜下出血, 脳動脈瘤症例の退院後追跡調查, 秋医誌, 24(2) : 85, 1972.

\title{
第 3 回 バイオメカニズム・シンポジウム（1973）
}

\author{
主催「バイオメカニズム研究会（SOBIM Japan）」
}

日 時 昭和 48 年 7 月 12 日（木） 13 日（金） 14 日 (土)

会 場 福島市飯坂温泉 福島市飯坂町中/内 $1-1$ あづま荘 TEL 02454-2-3381

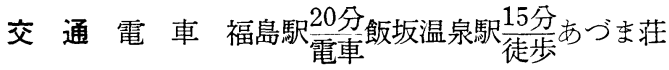
バ ス 福島駅前より飯坂行終点若葉町下車 徒歩 10 分 宗原行飯坂町終点下車 徒歩 1 分

登録料 1. 一般参加者 7,500 円

2. 学 生 5,000 円

3. 論文発表者 4,000 円

論文の共著者が参加される場合も一般参加と して登録して下さい.

登録された方には予稿集・単行本くバイオメ カニズム第 2 集 $>$ 仮題（東大出版会 予価 4,500）を1部さしあげます.

定員 180 名
宿 舎 会場である飯坂温泉あづま荘は貸切になって おりますので登録された方には順次御紹介致 します。

宿泊料金は 5,600 円（2泊 4 食付）です．宿 泊人数には制限がありますので定員に達しし だい宿舎斡旋は締切らせて頂きます。

申込締切登録および宿舎予約申込期限は 5 月 31 日 としますが，定員になり次第締切りますので 参加御希望の方は早めに御予約下さい.

申込先 申込用紙に登録料および宿舎料金をそえて下 記にお申又下さい。

東京都新宿区西大久保 4-170 ( $=160$ ) 早稲田大学理工学部 58-214 号室 加藤研究 室内

$$
\text { バイオメカニズム研究会 }
$$

TEL（03）209-3211 内線 228

振替口座 東京 178686 番 東京都民銀行西大久保支店 213460 番 